https://doi.org/10.15407/geotech2020.32.015

УДК 621.039 .7

\title{
Ольховик Ю.О.
}

Ольховик Ю.О., д.т.н., завідувач відділу, ДУ «ІГНС НАН України», ORCID:0000-0001-5653-2370 , yolkhovyk@ukr.net

\section{ГЕОЛОГІЧНЕ СХОВИЩЕ ВИСОКОАКТИВНИХ ВІДХОДІВ В УКРАЇНІ: ПРО- БЛЕМИ ТА ПЕРСПЕКТИВИ СТВОРЕННЯ}

3 огляду на сучасні тендениії розвитку науково-технічних рімень щэодо забезпечення довгострокової безпеки при геологічному захороненні високоактивних радіоактивних відходів включно із відпрацьованим ядерним паливом, розглянуто наявні в Україні проблеми, які необхідно враховувати при створенні геологічного сховища. Відзначено необхідність інтенсифікації розробки і реалізації програм і стратегій поводження з відпрацьованим ядерним паливом і високоактивними радіоактивними відходами з періодом планування до 100 -150 років. Основою програм створення геологічного сховища мають стати результати опрацювання реєстру ВАВ (високоактивних радіоактивних відходів) та концептуальні рішення з геологічного захоронення, а самі програми і стратегії повинні відповідати вимогам відкритості і публічного обговорення науковою спільнотою. Наразі настає час законодавчого визначення - який саме ядерний паливний иикл: відкритий (без переробки відпращьованого ядерного палива) чи закритий більше відповідатиме економічним, екологічним цілям та можливостям України. 3 огляду на зміни в законодавстві підкреслено необхідність визначитися з очікуваними обсягами РАВ (радіоактивних відходів), щчо можуть бути захоронені в геологічному сховищі, $i$ для яких саме відходів необхідно створювати національне геологічне сховище. Значна невизначеність щзодо об'ємів $і$ строків надходження на захоронення притаманна відходам від переробки відпрачьованого ядерного палива реакторів ВВЕР-1000 на Красноярському гірничо-хімічному комбінаті. Оиінка обсягів відпрацьованого ядерного палива нових енергоблоків АЕС та термінів, протягом якого вони будуть утворюватися, має враховувати різні варіанти стратегії розвитку енергетичного комплексу Украӥни. Зазначено, щзо виключення з Конщепиії нової Загальнодержавної програми поводження з РАВ питань щодо майбутнього захоронення відпрацьованого ядерного палива не відповідає міжнародно-правовим зобов'язанням Украйни у сфері європейської інтеграції з питань, щңо стосуються сфери безпеки використання ядерної енергії.

Ключові слова: геологічне сховище, відпрацьоване ядерне паливо, високоактивні відходи, законодавство Украӥни

Актуальність теми визначається сучасними тенденціями розвитку науково-технічних рішень щодо забезпечення довгострокової безпеки при геологічному захороненні високоактивних радіоактивних відходів (ВАВ) включно із відпрацьованим ядерним паливом (ВЯП), які необхідно враховувати при створенні в Україні геологічного сховища.

Концепція глибинного геологічного захоронення ВАВ досліджувалася протягом кількох десятиріч i має високий рівень довіри серед експертів науковотехнічного співтовариства. Існує впевненість, що цей підхід здатний надійно ізолювати відходи від біосфери до того часу, доки вони створюють значні ризики - на період до одного мільйона років.

Сховище для ізоляції ВАВ має бути розміщено в такому геологічному середовищі, яке зберігає свої ізолюючі властивості протягом періоду, необхідного для досягнення безпечного рівня активності, і ефективно перешкоджає міграції радіонуклідів до біосфери. При цьому надійність ізоляції ВАВ забезпечується шляхом створення багатобар'єрної системи природних та інженерних бар'єрів, де природні бар'єри з часом набувають вирішального значення. Активний адміністративний контроль (підтримка цілісності бар'єрів сховища, моніторинг, нагляд) має здійснюватися лише на стадії експлуатації сховища.

Але також можливий гнучкий підхід до процесу прийняття рішень щодо захоронення ВЯП, що дозволило б майбутнім поколінням самостійно визначити стратегію довготривалого поводження з цими видами ВАВ. Такий підхід реалізує розроблена у Франції концепція оборотного захоронення ВЯП у глибинних геологічних формаціях, яка закріплена на законодавчому рівні і містить вимогу щодо забезпечення можливості для вилучення захоронених відходів протягом щонайменше 100 років.

Після закриття сховища безпека системи захоронення визначається реалізованими проектними рішеннями, бар'єрними властивостями геологічного середовища і деякий час пасивним адміністративним контролем, який являє собою обмеження певних видів діяльності людини в районі розташування сховища. 
Метою використання декількох бар'єрів є ефективне запобігання виносу радіонуклідів протягом необхідного періоду ізоляції, впродовж якого окремі складові системи мають бути взаємопов'язані і доповнювати одне одну щодо їх ефективності.

Це відноситься до двох основних груп - природних (геологічних) та штучних (технічних) бар'єрів. Ефективність штучних бар'єрів залежить від часу, i в основному обумовлюється геологічними умовами, а застосування технічних бар'єрів, навпаки, підсилює ізолюючі властивості геологічних умов. Прикладом цього є захоронення ВАВ у кристалічних формаціях. Тут дорогі технічні бар'єри, наприклад, контейнери 3 міді та бентонітовий тампонаж, компенсують недоліки скальних порід, які є проникні для води. 3 іншого боку, функціональні характеристики і ефективність цих технічних бар'єрів вимагають геологічного оточення зі стабільними гідрогеохімічними умовами в зонах дуже уповільненого (застійного) водообміну.

Геологічне захоронення технічно можливе i не представляє особливих проблем з інженерної точки зору [1]. Ця впевненість базується на:

- $\quad$ розумінні процесів та подій, які пов'язані з міграцією радіонуклідів зі сховища до біосфери;

- $\quad$ математичних моделях, які, використовуючи інформацію про конкретні геохімічні умови майданчика розміщення сховища та особливості технологій, що застосовані в проекті, забезпечують отримання надійних, довготермінових прогнозів впливу захоронених радіоактивних відходів на навколишнє середовище;
- вивченні природних аналогів вміщуючих порід сховища, які надають докази того, що ключові процеси при моделюванні геологічних систем протягом тривалого періоду враховано, включаючи режим сучасних геологічних рухів земної кори.

Наявність та доступність вищезазначених даних будуть сприяти зміцненню довіри суспільства щодо можливості забезпечити захист нинішнього і майбутніх поколінь, що $є$ фундаментальною етичною вимогою. Цей захист має найвищий пріоритет, тому що при неможливості забезпечити достатній рівень безпеки, усі інші аспекти (фінансові, політичні) стають вкрай незначними.

Національною академією наук США проголошено: «Тільки геологічне захоронення залишається науково і технічно надійним довгостроковим рішенням, що задовольняє необхідному рівню безпеки і не залежить від активного управління. Добре спроектоване сховище після закриття являє собою пасивну систему, що містить надійну систему бар'єрів безпеки. Ми здатні проектувати, будувати і використовувати технологічні об'єкти з набагато більшою складністю і вищим потенціалом безпеки» [2].

Більшість країн, які мають ядерні енергетичні програми, визначили пріоритетним технічним підходом остаточне захоронення високоактивних РАВ у геологічних сховищах (ГС) шахтного типу на глибинах у сотні метрів. В ядерних країнах на державному рівні ведеться розробка і реалізація програм і стратегій поводження з ВЯП і ВАВ із періодом планування до 150 років (рис.1) [3].

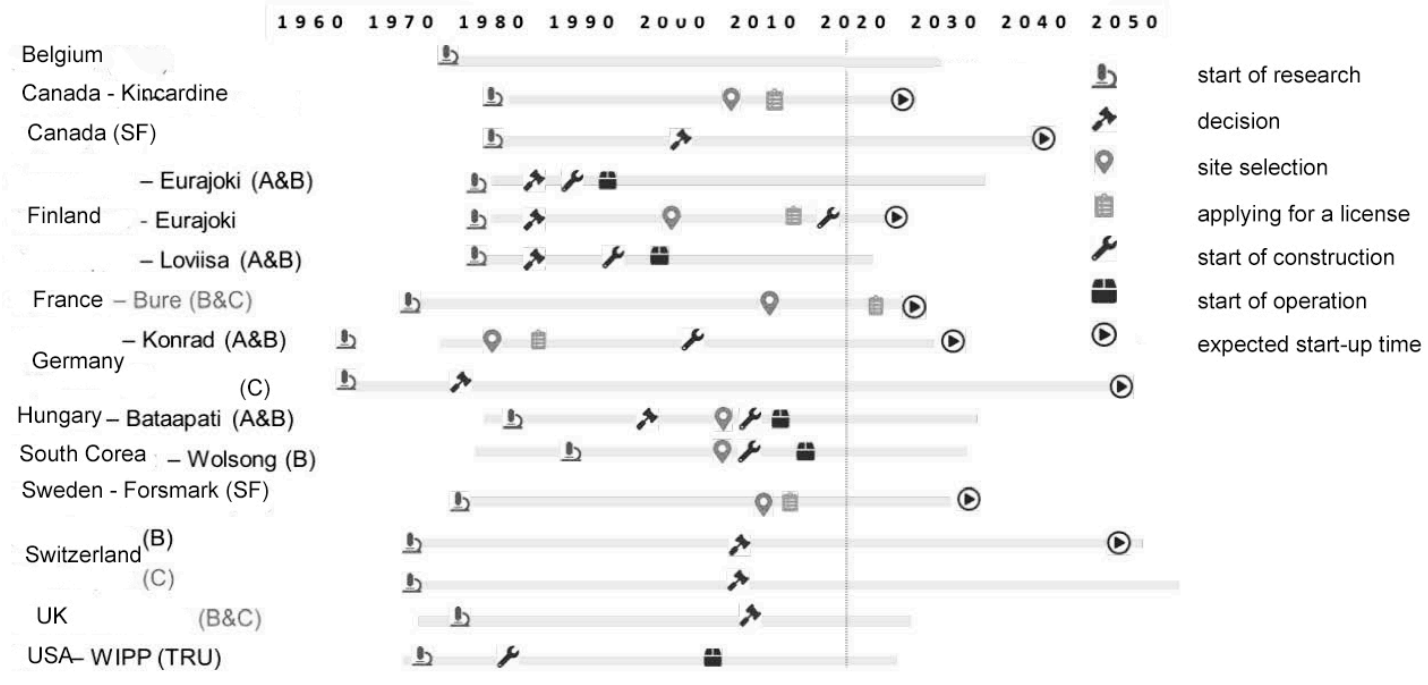

Рис.1 Тривалість основних етапів створення геологічного сховища відповідно до існуючої практики за кордоном Fig.1 The main stages of a geological repository construction in accordance with the existing practices abroad 
Програми базуються на детальному опрацюванні реєстру ВАВ, концептуальних рішень з геологічного захоронення, послідовності дій по спорудженню та експлуатації об'єктів захоронення. Повсюдно програми і стратегії створення ГС характеризуються високим рівнем відкритості та публічної дискусії. Проте у багатьох країнах громадськість і політики, 3 різних причин, заперечують створення сховища для ядерних відходів. Прикладом останнього є ситуація у США, де створення геологічного сховища ЯккаМаунтін паралізовано через політичні мотиви. У деяких країнах відбувається уповільнення або навіть припинення ліцензування нових атомних електростанцій через відсутність очевидного прогресу відносно захоронення відходів.

Хоча геологічне захоронення проголошено технічною стратегією у багатьох країнах, $є$ істотні відмінності у тому, як вони планують їі реалізовувати. Метою досліджень є аналіз підходів та концепцій, які мають бути враховані при розробці концепції проекту геологічного сховища, що має розглядатися як перший крок до розробки загальнодержавної цільової екологічної програми створення геологічного сховища в Україні.

\section{Законодавче забезпечення}

Створення геологічного сховища для захоронення радіоактивних відходів (РАВ) передбачено Законом України «Про поводження 3 радіоактивними відходами» [4] із змінами відповідно до Закону України від 17.10.2019 року №208 «Про внесення змін до деяких законів України щодо вдосконалення законодавства у сфері поводження 3 радіоактивними відходами» [5] таким чином: «Зберігання та захоронення радіоактивних відходів дозволяється виключно у спеціально призначених для цього сховищах відповідного типу, а саме: поверхневому сховищі, приповерхневому сховищі, сховищі для захоронення радіоактивних відходів на середніх глибинах, геологічному сховищі. Тип сховища для захоронення радіоактивних відходів визначається відповідно до класу радіоактивних відходів» (ст.17). Цією ж статтею було вперше законодавчо визначено статус відпрацьованого ядерного палива - це не відходи, а цінна сировина, яка підлягає безстроковому зберіганню. Після ратифікації «Об’єднаної конвенції про безпеку поводження 3 ядерним паливом та безпеку поводження з радіоактивними відходами» [6] Україна набула право самостійно визнавати ВЯП радіоактивними відходами і, відповідно, направляти таке ВЯП або деякі його партії на захоронення (ст.10).

В Законі України «Про порядок прийняття рішень про розміщення, проектування, будівництво ядерних установок і об'єктів, призначених для поводження $з$ радіоактивними відходами, які мають зага- льнодержавне значення» [7] визначено, що до ядерних установок і об'єктів, призначених для поводження з РАВ, які мають загальнодержавне значення, належать, у т.ч. геологічні сховища, призначені для захоронення ВЯП або РАВ (ст.1).

Рішення про розміщення, проектування, будівництво геологічного сховища, яке, безумовно, матиме загальнодержавне значення, приймаються Верховною Радою України шляхом прийняття відповідного закону (ст.2).

Рішення про погодження розміщення на своїй території геологічного сховища місцеві органи виконавчої влади і органи місцевого самоврядування приймають після проведення місцевого дорадчого опитування громадян України (консультативного референдуму) з цього питання (ст.3).

Існуючою на сьогодні Загальнодержавною цільовою екологічною програмою поводження з РАВ [8] передбачено виконання комплексу пошукових, оціночних, науково-методичних, дослідницьких i проектних робіт 3 вибору майданчиків для розміщення геологічного сховища для захоронення довгоіснуючих та високоактивних РАВ із відповідним фінансуванням. Проте дія цієї Програми не поширюється на поводження з відпрацьованим ядерним паливом, яке може, відповідно до вимог законів [5] та [6], бути призначене для безпосереднього захоронення.

Прийняття законодавчого акту [5] дозволило ліквідувати колізії щодо статусу ВЯП, що підлягає безпосередньому захороненню у геологічному сховищі, відповідно до вимог Об'єднаної конвенції із попередньою редакцією Закону України «Про поводження з радіоактивними відходами».

Цим же законодавчим актом прийнято класифікацію РАВ, яка відповідає узгодженим на міжнародному рівні стандартам безпеки, і базується, перш за все, на міркуваннях щодо довгострокової безпеки захоронення.

Роботи зі створення геологічного сховища потребуватимуть на перших етапах:

1. Затвердження програми створення геологічного сховища після розробки нової загальнодержавної програми поводження з РАВ і ВЯП у частині створення ГС для безпосереднього захоронення PAB, у тому числі у вигляді ВЯП.

2. Затвердження майданчика розміщення ГС по завершенню пошукових, дослідницьких робіт та робіт із розробки техніко-економічного обгрунтування проекту та наявності позитивних результатів після погодження та підтримки проекту місцевою громадою, у відповідності до вимог законодавства України», в районі розміщення сховища. 
3. Затвердження проекту геологічного сховища та ін.

Навіть якщо ВЯП призначені для безпосереднього захоронення, вони все одно будуть зберігатися у поверхневих сховищах протягом багатьох років через високу активність $\left(10^{17}-10^{18}\right.$ Бк/т ВЯП), а також внаслідок довготривалості процесу створення геологічного сховища. Через 30 років витримки після вивезення ВЯП 3 приреакторних басейнів, тепло від розпаду продуктів поділу (в основному цезію-137 та стронцію-90), які будуть основними джерелами тепла в цей період, зменшиться приблизно у два рази, а через 100 років внесок від цих ізотопів у енерговиділення знизиться більше ніж на 90\%. При цьому випромінювання від продуктів поділу слугує значною перешкодою, яка ускладнює спроби потенційних шукачів ядерної зброї з виділення плутонію з ВЯП, що є бажаним з позиції нерозповсюдження. Цей факт є ще одним з аргументів на користь тривалого зберігання ВЯП у централізованому сховищі як в Україні, так і в інших країнах, де експлуатуються АЕС

На сьогодні існує два варіанти вирішення проблем поводження з ВЯП:

- $\quad$ пряме захоронення ВЯП (у якості відходів) після тимчасового зберігання, достатнього для розпаду короткоіснуючих радіонуклідів;

- $\quad$ захоронення кондиціонованих ВАВ від переробки ВЯП після вилучення урану та плутонію, а також інших радіонуклідів.

При прийнятті рішення про переробку ВЯП необхідно враховувати такі економічні витрати, як вплив на безпеку і навколишнє природне середовище та ризики розповсюдження ядерних матеріалів. Крім того, ця діяльність буде джерелом додаткових ризиків для персоналу та населення, а також утворення значних обсягів РАВ, що містять довгоіснуючі трансуранові радіонукліди. Тому значна частина цих відходів, в кінцевому рахунку, мають бути захоронені у геологічному сховищі. Вартість усієї схеми виділення деяких радіонуклідів у ВЯП значно перевищить вартість відкритого паливного циклу (пряме захоронення ВЯП).

Різні радіонукліди в різні періоди стають домінуючими вкладниками до загальної радіоактивності та енерговиділення ВЯП внаслідок радіоактивного розпаду.

Виділення (екстракція) радіонуклідів - продуктів поділу, що відповідають за інтенсивне тепловиділення (так звана цезій-стронцієва фракція) 3 ВЯП та окреме кондиціонування і зберігання, дозволить розмістити їх у більш компактному об'ємі в геологічному сховищі. Разом із тим слід зазначити, що подібний результат може бути досягнутий і без переробки ВяП - за рахунок зберігання ВЯП протягом декількох де- сятиліть, до розпаду продуктів поділу.

США, Канада та Фінляндія відносяться до країн, які планують безпосередньо захороняти ВЯП. Друга група країн - Великобританія та Франція, планують здійснювати переробку ВЯП і проводити захоронення осклованих ВАВ. Третя група країн, у тому числі і Україна, передбачають тривале зберігання ВЯП, що визначено у Концепції Державної економічної програми поводження 3 відпрацьованим ядерним паливом вітчизняних атомних електростанцій на період до 2024 року [9]. У 2020 році очікується введення в експлуатацію Централізованого сховища відпрацьованого ядерного палива, призначеного для зберігання ВЯП з трьох українських АЕС. Деякі країни, зокрема Японія та РФ, оголосили про заборону прямого захоронення ВЯП.

Принципові питання, які мають бути вирішені до початку розробки програми створення геологічного сховища. Як зазначено раніше, чинна Загальнодержавна цільова екологічна програми поводження з РАВ, затверджена Законом України від 17 вересня 2008 року №516-VI [8], передбачає виконання комплексу робіт з вибору майданчиків для розміщення геологічного сховища.

Проект Концепції нової Загальнодержавної цільової екологічної програми поводження з радіоактивними відходами на період 2020 - 2030 рр. не розглядає будь-яких питань захоронення ВЯП і наголошує, що заходи щодо поводження з ним не входять в обсяг Програми, що, на погляд автора, $є$ неправомірним 3 огляду на невідповідність вимогам Директиви Ради 2011/70/Свратом від 19 липня 2011 року [10]. Ст.11 Директива «Національні програми» наголошує, що кожна держава забезпечує імплементацію своєї національної програми управління відпрацьованим паливом та радіоактивними відходами («національна програма»), що охоплює всі типи відпрацьованого палива та радіоактивних відходів у межах іiі юрисдикції та всі етапи управління відпрацьованим паливом та радіоактивними відходами - від утворення до захоронення. Застосований у Концепції нової Програми підхід може суттєво загальмувати розробку концептуальних вимог i програми створення ГС.

У різних країнах це питання вирішується порізному. Наприклад, у Німеччині Федеральним міністерством охорони довкілля, збереження природи та ядерної безпеки було визначено основні фундаментальні вимоги до геологічного сховища, а саме:

- $\quad$ всі РАВ мають бути захоронені у глибоких геологічних формаціях у Німеччині. 
- $\quad$ усі обсяги РАВ будь-яких категорій мають бути розміщені в одному сховищі, яке має бути введено в експлуатацію у 2030 році [11].

Отже, до розробки Програми створення геологічного сховища необхідно визначитися з очікуваними обсягами РАВ, що можуть бути захоронені в ньому, і для яких саме відходів необхідно створювати національне геологічне сховище.

Розробка проекту програми створення геологічного сховища. У разі прийняття рішення щодо розробки окремої Програми створення ГС, її проект має розроблятися у відповідності до вимог закону України «Про державні цільові програми» [12] та «Порядку розроблення та виконання державних цільових програм», затвердженого постановою КМУ в 2007 p. [13].

Основними стадіями розроблення державної цільової програми $є$ :

концепції програми;

- $\quad$ схвалення концепції програми та прийняття рішення щодо розроблення проекту програми, визначення державного замовника та строків іiі розроблення;

- $\quad$ розроблення проекту програми - визначення заходів і завдань, що пропонуються для включення до неї, а також обсягів і джерел фінансування;

• державна експертиза проекту програми;

- погодження та затвердження програми;

- $\quad$ проведення конкурсного відбору виконавців заходів і завдань програми;

- $\quad$ організація виконання заходів і завдань програми, здійснення контролю за їх виконанням;

- $\quad$ підготовка та оцінка щорічних звітів про результати виконання програми, а в разі потреби проміжних звітів;

- підготовка та опублікування в офіційних друкованих виданнях заключного звіту про результати виконання програми.

Проект концепції Програми має містити, у т.ч. такі розділи:

- $\quad$ визначення проблеми, на розв'язання якої спрямована програма;

- $\quad$ аналіз причин виникнення проблеми та обгрунтування необхідності іiі розв'язання програмним методом;

- $\quad$ мета програми;
- визначення оптимального варіанта розв'язання проблеми на основі порівняльного аналізу можливих варіантів;

- шляхи i способи розв'язання проблеми, строк виконання програми;

- очікувані результати виконання програми, визначення іiі ефективності;

- оцінка фінансових, матеріально-технічних, трудових ресурсів, необхідних для виконання програми.

Проект програми розробляється державним замовником (або визначеним ним розробником) на основі схваленої концепції. Розробці зазначених документів сприятиме імплементація результатів виконання в Україні Проекту INSC - U4.01/14B «Розробка національного плану геологічного захоронення радіоактивних відходів в Україні та графіка його реалізації», основними цілями якого $є$ :

- Визначення процесу, який дозволить вибрати технічно придатний та соціально прийнятний майданчик для розміщення сховища РАВ;

- Розробка детального плану та кошторису витрат для глибокого геологічного захоронення в Україні;

- Навчання фахівців з оцінки безпеки, обгрунтування безпеки, управління програмами тощо, стосовно до розробки глибокого геологічного сховища.

- Підтримка у формуванні позитивного ставлення громадськості до процесу вибору майданчика для розміщення геологічного сховища РАВ в Україні, з урахуванням міжнародної практики створення подібних об'єктів.

Розробка концепції проекту геологічного сховища. Розробити проект та концепцію Програми створення геологічного сховища можна, на думку автора, лише за умови наявності узгодженої із зацікавленими науковими і проектними організаціями та зацікавленими міністерствами та відомствами Концепції геологічного сховища.

Основні положення концепції ГС зрозумілі і мають бути запропоновані та вирішені на основі результатів детальних досліджень, вишукувань та науково-технічних обгрунтувань, це в першу чергу:

- $\quad$ вибір відповідної геологічної формації (кристалічні, осадкові (глини, солі) або комбінація різних формацій з різними фізико-хімічними характеристиками;

- $\quad$ вибір та обгрунтування конструкції ГС шахтного чи свердловинного типу;

- основні проектні рішення щодо вибору та обгрунтуванню кількості та складу основних інже- 
нерних бар'єрів, транспортно-технологічних рішень щодо переміщення упаковок, схем розміщення упаковок тощо.

Проте ряд питань потребує детального розгляду та підготовки проектів рішень на державному, у т.ч. законодавчому рівні, перш за все обсяги та категорії $\mathrm{BAB}$, для захоронення яких має бути споруджено геологічного сховище у глибоких геологічних формаціях. Серед них головними є:

- ВЯП реакторів РБМК (енергоблоки 1-3 ЧАЕС, обсяги відомі). Переробка зазначеного виду ВЯП в СРСР не планувалася.

- Відходи від переробки ВЯП реакторів ВВEР-1000, що планувалися до повернення в Україну після переробки на радіохімічному підприємстві PT-2 на Красноярському горно-хімічному комбінаті (ЗАЕС, РАЕС, ХАЕС, ЮУАЕС всього 13 блоків, обсяги прогнозовані) - цей об'єкт планують ввести в експлуатацію у 2025 році, але 3 огляду на складності доопрацювання нових технологій переробки ВЯП до промислового рівня, зазначений строк не $є$ остаточним, що накладає велику невизначеність щодо виду і часу повернення в Україну відповідних відходів

- Оскловані відходи від переробки ВЯП реакторів ВВЕР-440 РАЕС на РТ-1 (об'єми визначені i складають $260 \mathrm{~m}^{3}$, проект «Будівництво сховища для проміжного зберігання високоактивних відходів, які повертаються з РФ після переробки відпрацьованого ядерного палива українських АЕС» на стадії узгодження).

- ВЯП, що зберігається у сухих сховищах на майданчиках Запорізької АЕС і в зоні відчуження (обсяги прогнозовані).

- ВЯП нових енергоблоків АЕС (обсяги та терміни утворення важко прогнозовані). При цьому оцінка обсягів ВЯП та термінів, протягом якого вони будуть утворюватися, має враховувати різні варіанти стратегії розвитку енергетичного комплексу України

- Високоактивні відходи внаслідок проведення робіт із ліквідації наслідків аварії на ЧАЕС, перетворення нового безпечного конфайнменту, із залишками зруйнованого енергоблоку, на екологічно безпечну систему (обсяги відходів та терміни їх утворення можуть бути прогнозовані).

- ВЯП дослідницьких реакторів та відпрацьовані джерела іонізуючого випромінювання.

Орієнтовно кількість некондиційованих ВАВ для захоронення у геологічному сховищі може перевищити $60000 \mathrm{~m}^{3}$ [14].

Внаслідок прийняття Верховною Радою України закону України від 17.10.2019 року №208 «Про вне- сення змін до деяких законів України щодо вдосконалення законодавства у сфері поводження з радіоактивними відходами» виникає дилема: чи буде достатнім для усіх РАВ України одного геологічного сховища у глибоких формаціях, чи потрібно створювати ще одне геологічне сховище для захоронення середньоактивних довгоіснуючих відходів на глибинах у декілька сотень метрів. Такими довгоіснуючими відходами може стати опромінений реакторний графіт, що складає активну зону реакторів РБМК енергоблоків 1-3 Чорнобильської АЕС, які знімаються $з$ експлуатації. Радіологічна небезпека опроміненого графіту пов'язана із притаманною йому значною активністю довгоіснуючих радіонуклідів ${ }^{14} \mathrm{C} \mathrm{i}{ }^{36} \mathrm{Cl}$, які мають великі періоди напіврозпаду -5730 та 301000 років відповідно і у природних умовах мають високу міграційну здатність. Загальний об’єм графітової кладки, який становить 3700 м $^{3}$, можна порівнювати із загальним об’ємом ВЯП, що можуть бути розміщені у глибоких геологічних формаціях.

\section{Висновки}

1. Проект Програми створення геологічного сховища РАВ у глибоких геологічних формаціях має базуватися на Концепції геологічного сховища, яка має бути сприйнята науково-технічним співтовариством України та відповідним чином затверджена.

2. При розробці Концепції ГС необхідно періодично проводити техніко-економічний аналіз варіантів загальнодержавної системи поводження 3 високоактивними і середньоактивними довгоіснуючими відходами 3 точки зору забезпечення їх гарантовано безпечного захоронення, і застосовувати планування створення об'єктів захоронення, що орієнтовані на конкретні РАВ.

3. Діяльність національного оператора з поводження з РАВ щодо розробки програми і стратегії створення ГС має відповідати вимогам відкритості та публічного обговорення 3 науково-технічною громадськістю України.

4. Беручи до уваги довгостроковість етапів створення ГС і обмежені строки функціонування Централізованого сховища ВЯП і сухого сховища ВЯП на Запорізькій АЕС, виключення з Концепції нової Загальнодержавної програми поводження 3 РАВ питань щодо майбутнього захоронення ВЯП $є$ необгрунтованим i не відповідає міжнародноправовим зобов'язанням України у сфері європейської інтеграції з питань, що стосуються сфери безпеки використання ядерної енергії. 


\section{Література}

1. International Atomic Energy Agency. "Scientific and Technical Basis for the Geologic Disposal of Radioactive Wastes”, Technical Report No.413. IAEA, Vienna, 2003.

2. National Academy of Sciences, Board on Radioactive Wastes Management, Disposition of High level Waste and Spent Nuclear Fuel. The Continuing Societal and Technical Challenges, National Academy Press, Washington, D.C., 2001.

3. Strategic Briefing on the Progress on High-level Waste Disposal in NEA Member Countries, 18 April 2019

4. Закон України «Про поводження з радіоактивними відходами» від 30.06.1995 р. №255/95-ВР. [Електронний pecypc] URL: https://zakon.rada.gov.ua/laws/show/255/95\%D0\%B2\%D1\%80

5. Закон України «Про внесення змін до деяких законів України щодо вдосконалення законодавства у сфері поводження з радіоактивними відходами» від 17.10.2019 року №208 [Електронний ресурс] URL: https://zakon.rada.gov.ua/laws/show/208-20

6. Закон України «Про ратифікацію Об'єднаної конвенції про безпеку поводження з ядерним паливом та безпеку поводження 3 радіоактивними відходами» від 20.04.2000 p.№1688. [Електронний ресурс] URL:https://zakon.rada.gov.ua/laws/show/1688-14

7. Закон України «Про порядок прийняття рішень про розміщення, проектування, будівництво ядерних установок і об'єктів, призначених для поводження з радіоактивними відходами, які мають загальнодержавне значення» від 08.09.2005 p. №2861. [Електронний ресурс] URL:https://zakon.rada.gov.ua/laws/show/2861-15

8. Закон України «Про затвердження Загальнодержавної цільової екологічної програми поводження з радіоактивними відходами» від 17.09.2008p №516. [Електронний pecypc] URL:https://zakon.rada.gov.ua/laws/show/516-17

9. Розпорядження Кабінету Міністрів України від 5 червня 2019 р. № 385-р «Про схвалення Концепції Державної економічної програми поводження з відпрацьованим ядерним паливом вітчизняних атомних електростанцій на період до 2024 року» [Електронний ресурс] URL:https://zakon.rada.gov.ua/laws/show/385-2019-\%D1\%80

10. Директива Ради 2011/70/СВРАТОМ від 19 липня 2011 року про запровадження рамок Співтовариства для відповідального та безпечного управління відпрацьованим паливом та радіоактивними відходами. - [Електронний pecypc] URL:https://zakon.rada.gov.ua/laws/show/984_00411

11. Site Selection procedure for Repository Sites. Recommendations of the AkEnd - Committee on a Site Selection procedure for Repository Sites. Koln, 248 p., 2002.

12. Закон України «Про державні цільові програми» від 18.03.2004 №1621-IV. [Електронний ресурс] URL:https://zakon.rada.gov.ua/laws/show/1621-15

13. «Порядок розроблення та виконання державних цільових програм» затверджено постановою КМУ від 31.01.2007 p №106. [Електронний ресурс] URL: https://zakon.rada.gov.ua/laws/show/106-2007-\%D0\%BF
14. В. М. Шестопалов, Ю. О. Шибецький Геологічне захоронення радіоактивних відходів в Україні: історія, сучасний стан, перспективи. Ядерна та радіаційна безпека. 2017. № 2(74). c. 38 - 45.

\section{References}

1. International Atomic Energy Agency., Technical Report No.413 (2003) IAEA, Vienna.

2. National Academy of Sciences, Board on Radioactive Wastes Management, Disposition of High level Waste and Spent Nuclear Fuel. The Continuing Societal and Technical Challenges, (2001) National Academy Press, Washington, D.C.

3 Strategic Briefing on the Progress on High-level Waste Disposal in NEA Member Countries, 18 April 2019

4. Law of Ukraine "On Radioactive Waste Management" №255.

5. Law of Ukraine "On Amendments to Certain Laws of Ukraine on Improving Legislation in the Sphere of Radioactive Waste Management" №208 Available at: https://zakon.rada.gov.ua/laws/show/208-20

6. Law of Ukraine "On Ratification of the Joint Convention on the Safety of Nuclear Fuel Management and the Safety of Radioactive Waste Management”. Available at: https://zakon.rada.gov.ua/laws/show/1688-14

7. Law of Ukraine "On the Procedure for Making Decisions on the Location, Design, Construction of Nuclear Installations and Facilities Intended for the Management of Radioactive Waste of National Importance” №2861. Available at: https://zakon.rada.gov.ua/laws/show/2861-15

8. Law of Ukraine "On Approval of the National Targeted Environmental Program for Radioactive Waste Management” №516. Available at: https://zakon.rada.gov.ua/laws/show/51617

9. Order of the Cabinet of Ministers of Ukraine of June 5, 2019 № 385-r "On approval of the Concept of the State Economic Program for the management of spent nuclear fuel of domestic nuclear power plants for the period up to 2024" Available at: https://zakon.rada.gov.ua / laws / show / 3852019-\% D1\% 80

10. Council Directive 2011/70 / EURATOM of 19 July 2011 establishing a Community framework for the responsible and safe management of spent fuel and radioactive waste. Available at: https://zakon.rada.gov.ua/laws/show/984_004-11

11. Site Selection procedure for Repository Sites. Recommendations of the AkEnd (2002). Committee on a Site Selection procedure for Repository Sites. Koln, 248 p.

12. Law of Ukraine "On State Target Programs" №1621. Available at: https://zakon.rada.gov.ua/laws/show/1621-15

13. "The order of development and implementation of state target programs" was approved by the resolution of the Cabinet of Ministers of 31.01.2007 №106. Available at: https://zakon.rada.gov.ua/laws/show/106-2007-\%D0\%BF

14. V.M. Shestopalov, Y.O. Shibetsky (2017). Yaderna ta radiatsiyna bezpeka.. V 2(74). pp. 38 - 45. 


\section{GEOLOGICAL STORAGE OF HIGHLY ACTIVE WASTE IN UKRAINE: PROBLEMS AND PRO-} SPECTS OF CONSTRUCTION

Yu. Olkhovyk, D. Sc. (Tech.), Head of Department, State Institution "The Institute of Environmental Geochemistry of the National Academy of Sciences of Ukraine", ORCID:0000-0001-5653-2370, yolkhovyk@ukr.net

Based on the current trends in the scientific and technical solution development that ensures the long-term safety of geological disposal of high-level radioactive waste, including spent nuclear fuel, the article presents the existing in Ukraine problems that need to be considered when constructing a geological repository. The development and implementation of the programs and strategies for the spent fuel and HLW management with a planning period up to 100 - 150 years should be intensified. The geological repository construction programs must be based on the results of the HLW register development and conceptual solutions for the geological disposal. The programs and strategies must meet the requirements for openness and public discussion in the scientific community. The time came to determine by law which nuclear fuel cycle is consistent with the economic and environmental goals, and capabilities of Ukraine: the open (without spent nuclear fuel reprocessing) or the closed. Considering the changes in the legislation, it is necessary to determine the expected radwaste amounts and the type of waste to be disposed in the geological repository. For example, the volume of waste from the processing of the spent fuel from VVER-1000 reactors at the Krasnoyarsk Mining and Chemical Plant (Russian Federation) and the time-schedule of its arrival for disposal are virtually undetermined. The assessment of the spent nuclear fuel volumes from new NPPs and the time period during which they will be formed should consider different strategies of the energy complex development in Ukraine. It is noted that the exclusion of the issues related to spent fuel disposal from the Concept of the new National Program of Radwaste Management does not comply with the international legal obligations of Ukraine in the field of the European integration on nuclear safety issues.

Keywords: geological repository, spent nuclear fuel, high-level waste, legislation of Ukraine 